University of Montana

ScholarWorks at University of Montana

Management and Marketing Faculty

Publications

Management and Marketing

Summer 2002

\title{
Leveraging Internet Technologies In B2B Relationships
}

Sandy D. Jap

Emory University

Jakki J. Mohr

University of Montana - Missoula, jakki.mohr@business.umt.edu

Follow this and additional works at: https://scholarworks.umt.edu/manmark_pubs

Part of the Marketing Commons

Let us know how access to this document benefits you.

\section{Recommended Citation}

Jap, Sandy D. and Mohr, Jakki J., "Leveraging Internet Technologies In B2B Relationships" (2002).

Management and Marketing Faculty Publications. 1.

https://scholarworks.umt.edu/manmark_pubs/1

This Article is brought to you for free and open access by the Management and Marketing at ScholarWorks at University of Montana. It has been accepted for inclusion in Management and Marketing Faculty Publications by an authorized administrator of ScholarWorks at University of Montana. For more information, please contact

scholarworks@mso.umt.edu. 


\title{
Leveraging Internet Technologies in B2B Relationships
}

\author{
Sandy D. Jap \\ Jakki J. Mohr
}

n the years 1999 and 2000, the prospects for B2B e-commerce were very rosy. In June 2000 , for example, Jupiter Communications' forecast called for more than $\$ 6$ trillion in online B2B, representing $42 \%$ of total U.S. B2B non-service spending. ${ }^{1}$ Their forecast was based on an expectation that online volume would grow 20 -fold between 2000 and 2005, opening the doors for new business models such as Internet markets and exchanges. Indeed, at the beginning of 2000 , there were $587 \mathrm{~B} 2 \mathrm{~B}$ exchanges on the Internet, which mushroomed to nearly 1700 exchanges by April 2001.

However, when the dot-com bubble burst, these B2B exchanges were among the hardest hit. Nearly 120 have been shut down or acquired, according to the research group at Deloitte Consulting. Similarly, predictions for B2B e-commerce have been tempered. The total value of goods and services purchased by businesses through e-commerce solutions is now predicted to increase from a solid $\$ 282$ in 2000 to $\$ 4.3$ trillion by 2005 , according to the November 2001 projections by International Data Corporation. ${ }^{2}$

Why has the B2B sector changed its tune? For one thing, companies have discovered that establishing successful B2B on-line strategies can be tough and complicated. Creating ecommerce activities that adds value to all participants, attracts suppliers, avoids gray markets, and decreases customer search and selection costs has proven to be difficult, if not downright impossible. Customers are inexperienced, solutions are disjointed, and technologies are unproven or inefficient. Implementation can be long, and scalability issues are complicated. In some cases, corporations have underestimated the value of the middleman, only to find that by cutting out the middleman, a significant amount of money has been lost. These firms find themselves spending the bulk of their time identifying and managing channel conflicts and assessing the sales gained/lost as a 
result. So, it appears that buying the technology is easy; rethinking and redesigning work processes and activities to capitalize on these technologies is not.

Despite these challenges, the B2B sector remains optimistic. More recent estimates indicate companies still expect to conduct the bulk of their direct and indirect materials spending through exchanges within 3 years. ${ }^{3}$ Indeed, Treasury Secretary Paul O'Neill has remarked, "The potential for productivity gains in the U.S. economy is higher than we realize. If you look at the penetration of good ideas, we're still at $20-30 \%$ level of what's possible." ${ }^{4}$ Similarly, half of the purchasing managers in recent surveys say that their companies stand to double their savings gained thus far from investments in computer networks. ${ }^{5}$ Evidently, executives still seem to believe that the promise of $\mathrm{B} 2 \mathrm{~B}$ e-commerce is real.

Exactly how the Internet will raise productivity-the goods and services produced from each hour of work-is still an open question. How can firms better manage their B2B e-commerce activities so as to capitalize on the economic opportunity while minimizing the pitfalls of those who have gone before? One of the largest stumbling blocks to leveraging emerging B2B technologies is the reality that they can undermine long-term business relationships that have been built and established over the course of many years. As a result, it is vital to ensure that one's e-commerce strategies are compatible with the types of relationships that have been developed in the customer or supply base. Hence, e-commerce technologies cannot be successfully leveraged without considering the organizational relationships in which the technologies are being embedded. Technologies do not operate in a vacuum, but exist in tandem with the processes, activities, and people operating at the boundaries of the firm. By appropriately matching the goals one is hoping to achieve in leveraging Internet technologies with the nature of the organization's relationships, companies can be in a better position not only to achieve the promised economic outcomes, but also to attain sustainable competitive advantages, improve coordination and collaboration processes, and decrease channel resistance.

This premise appears deceptively simple. Consider the scenario of a firm that wants to utilize the Web as a low-cost channel for reaching new consumers. On one hand, there are examples such as Herman Miller (HM) and its contract dealers. ${ }^{6}$ HM - known for its high-end, ergonomic office furniture-typically sells its premium cubicle systems to major corporations under big contracts at volume discounts. In 1998, the company began to reach out via the Web to individual customers such as telecommuters, freelancers, and small-business owners. After a communication and education campaign, HM successfully convinced all of its network dealers (its most strategic dealers) that the Internet channel reached new customers without eroding the dealer's existing customer base. The dealers realized that the handling and selling costs for these users did not justify the margin on the purchase, so dealers didn't mind that the on-line store pursued those customers, because their real focus was serving the major contracts. 
Thus, HM was able to successfully utilize the Internet as a means of reaching new customers and growing sales.

Now consider the case of Compaq Computer, which attempted a similar strategy, but experienced very different outcomes. ${ }^{7}$ In an attempt to take business away from Dell, Compaq created a unique set of business-oriented Prosignia computers for Internet-only sales and targeted the small and medium-size businesses, which weren't their dealers' primary sales focus. It also created a way for the dealers to profit from Internet referrals. However, the dealers viewed Compaq's activities as a sign of indifference toward their role and ultimately shunned selling any Compaq PCs, which had a crippling effect on the company.

In both cases, the manufacturers intended to use the Internet to reach new customers without cannibalizing the sales of their existing distributors, yet the firms experienced very different results. We contend that these differences may be the result of the type of organizational relationships that were in place at the time the Web-based efforts were developed. HM and their dealers had a history of working cooperatively to cover the costs associated with a customer's customization preferences. Together, they had crafted customer-specific access into HM's intranet to reflect the customer's business processes, volume pricing, and product preferences. They did not view the Internet channel as a threat to their existing business because they had a history of listening to HM's viewpoint and working collaboratively with them. On the other hand, Compaq's relationships with its dealers were historically contentious, with Compaq attempting power plays on the dealers. When it introduced the Prosignia line, Compaq began to deal in a more rigid fashion with the dealers, requiring them to adhere to minimum price rules and provide additional services. Against this backdrop. dealers were not convinced that Compaq had their interests in mind and didn't buy Compaq's arguments that their business would not be threatened. Thus, it may be that the types of relationships that were developed in these supply chains created a backdrop from which these chains viewed and responded to the opportunities created by new technologies.

\section{Relational and Transactional Exchanges}

The type of exchange relationships that firms craft with their suppliers or distributors varies widely, with one approach being adversarial or arm'slength in nature and the other being like a partnership. We refer to these types as transactional and relational exchanges, respectively. In transactional exchanges, the firm and its supplier compete for a fixed pie of benefits. Each side focuses on maximizing its own position at the other's expense. This is a common approach in many industries. Suppliers are selected by a competitive bid process and simply evaluated on price. Contracts are short-term, oriented around specific activities and timelines. There is no guarantee of business beyond the specific contract, and the buyer and supplier treat each other as adversaries in a 
zero-sum game. Communication with the supplier is directive, one-way, and doesn't take into consideration the perspective or interests of the supplier.

In a relational exchange, the firms focus less on fighting over shares of the pie and instead work together to expand and increase the mutual benefits. ${ }^{8}$ In these exchanges, suppliers are selected on the basis of their capabilities and the supplier takes full responsibility for the design, prototype, testing, and production of the product. The supplier may make dedicated investments to support its activities with the buyer and the contracts are long-term and less specific. There are considerable expectations beyond the contract terms. Performance evaluations are complex, multifaceted, and there is ample opportunity for supplier input in the communication process. The buyer and supplier work to insure that both parties make money. The partnering revolution of the 1990 s and the Japanese keiretsus are excellent examples of this type of approach.

Essentially, the relationships that are developed in transactional or relational exchanges differ in terms of their focus, orientation, type of communication, expectations beyond the contract, performance, and general attitudes. These relationships create a powerful backdrop within which the firms evaluate new opportunities, circumstances, and emerging technologies. These contexts may also determine whether the players see new Web-enabled efficiencies as a blessing or a curse, an opportunity or a threat.

\section{Web-Enabled Efficiencies}

While the Web allows opportunity for many types of efficiencies, we consider three here to illustrate the Relationship-Technology interface: information sharing, improved reach, and dynamic pricing. The Internet can enable improvements in the sharing of manufacturer, supplier, and distributor information all along the value chain, enabling each firm to better understand end-user needs and access market-level data that previously had been filtered or controlled by intermediary firms. The Internet also can enable manufacturers to increase their reach to new customer segments in a cheaper and more efficient manner. The Internet also enables real-time, dynamic pricing, making it easier than ever before to incorporate the "invisible hand of the market," and rely on price as a critical market-making mechanism. B2B electronic marketplaces that rely on auctions are the best exemplars of this aspect of Web-enabled efficiency.

\section{Relationship $\times$ Technology Matrix}

How might Web-enabled efficiencies best succeed in transactional or relational contexts? In particular, when are information sharing, improved reach, and dynamic pricing more or less likely to facilitate critical outcomes such as more efficient customer service and processes, improved relationship quality between the firms, enhanced cooperation with the supplier or distributor, and 
TABLE I. The Relationship X Technology Matrix

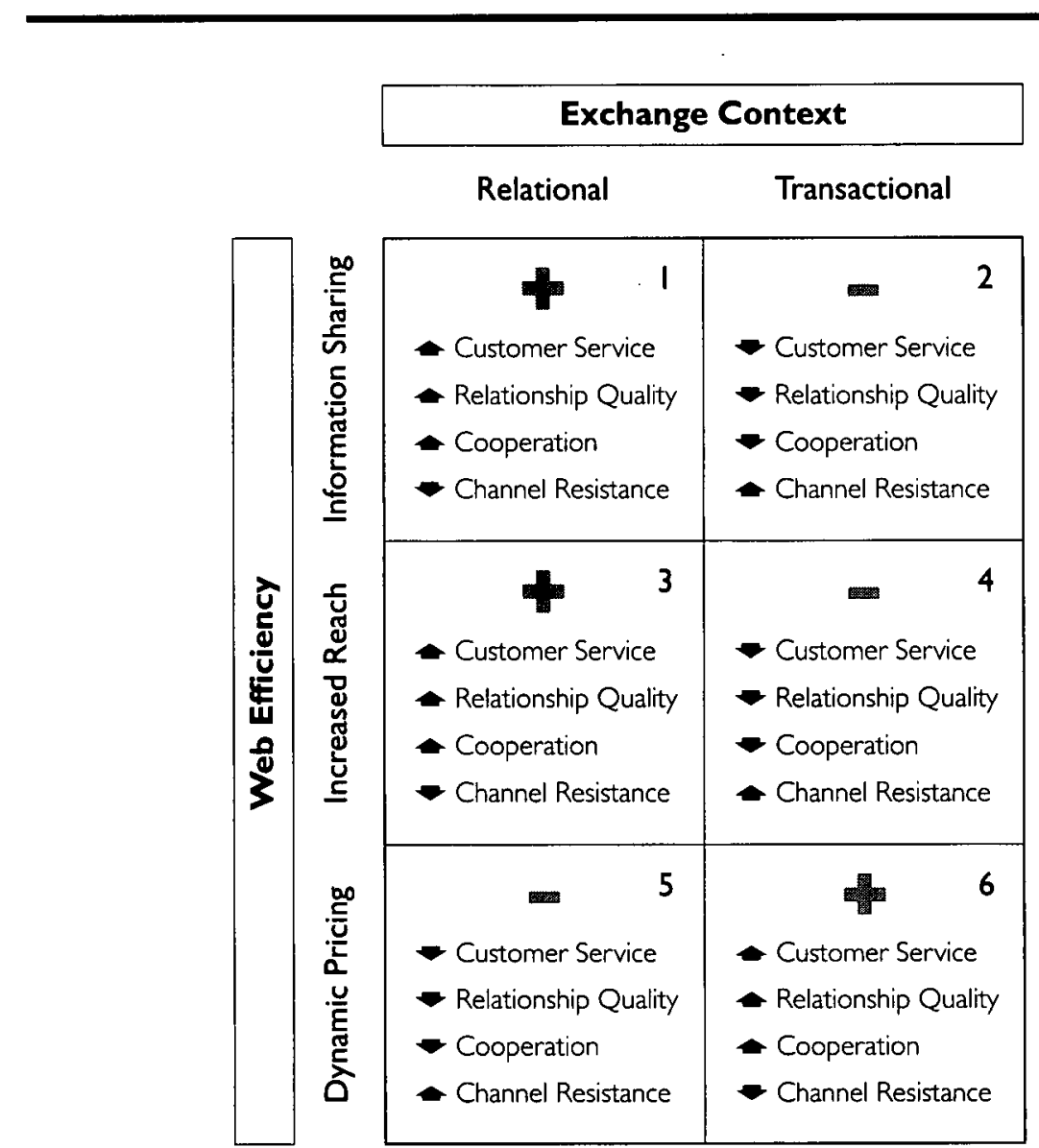

reduced channel resistance in a transactional or relational context? While these are potential outcomes from the Web-enabled efficiencies, they are not always achieved in B2B settings. Table 1 provides an overview of the Relationship $\times$ Technology matrix.

\section{Cell 1: Relational $\times$ Information Sharing}

In the first cell, when the Web is used to enhance information sharing in a relational context, the firms are more likely to experience positive outcomes: improved customer service, relationship quality, and cooperation, with decreased channel resistance. This is because in a relational context, the firms have developed a level of trust and expectation that the sharing of information such as sales forecasts, customer data, and production activities will be kept in confidence and not used opportunistically. 
In addition to using the Internet as a sales channel for new customers, Herman Miller also uses the Internet for information sharing purposes. HM had a history of working collaboratively with their dealers. Both sides knew that they were mutually committed to do what was best for both of them. Hence, when HM developed an intranet for corporate customers as a means to better share information, both dealers and HM saw it as an opportunity to improve the efficiency of their ongoing processes together. The idea was for HM's information technology staff, working closely with dealers around the country, to craft customer-specific access to the intranet to allow product preferences and volume pricing. Hence, customers could more easily configure and manage their purchases; dealers, freed from constantly traveling to clients' sites, could pursue more business. As a result, they were now in a better position to create strategic advantages over competing firms by having improved their ability to customize orders more accurately and efficiently than before. Because of the relational context already in place, neither HM nor the dealers perceived the sharing of more information as a threat of exposing their competitive position to the other.

Similarly, company extranets, that allow secure access to crucial information by suppliers, distributors, and customers, can work effectively in contexts where partners have a history of joint effort toward mutual gain. For example, Cisco has a history of working closely with its suppliers to provide superior customer service to its customers. Its efforts to link all of its contract manufacturers and suppliers into an advanced Web supply-chain management system-which speeds up the rate at which information about demand is distributed to suppliers-is compatible with its relationship tenor with suppliers.

\section{Cell 2: Transactional XInformation Sharing}

In a transactional setting, the sharing of information can be a threatening development. As more and more firms begin to share information about themselves on the Internet, many managers complain about the exposure of information. One manager said, "It used to be that our customers only knew good things about us through our advertisements and promotional materials. Now with our Web site and extranets, they know a lot more-the good, the bad, and the ugly."

Information is power. In many channels, control over information has been an ongoing struggle. For example, many auto manufacturers have faced the difficulty of getting information about customer transaction data and customer profiles from their dealers. Automakers can't be more responsive to customers as long as dealers control all the data. Dealers are not willing to divulge customer information, fearful that they will lose control over a key resource for the automaker. The resulting tensions have created decades of adversarial, arm's-length exchanges between the firms. This is one reason why Ford is willing to route customers directly to Priceline.com's auto buying service ${ }^{9}$ and why General Motors conducts elaborate market research. ${ }^{10}$ Armed with data that provides a better understanding of customer needs and motivations, the manufacturers can retool their factories so that customers have control over more 
options. However, these moves only further threaten dealers. Hence, in a transactional context, using the Internet to enable more information sharing may actually hinder firms' ability to improve customer service, relationship quality, and cooperation. It will also increase the dealer's resistance to accepting and relying on the Internet technologies in its exchange with the manufacturer.

One way to combat this potential negative effect is to recognize that dealers offer value through their services and knowledge of the customer, and should be treated as exchange partners that bring something worthwhile to the table. By treating dealers as partners instead of as competitors, the manufacturer can begin to cultivate trust and a sense of mutual concern, moving the transactional exchange in the direction of a relational exchange. The manufacturer may also need to be more proactive in helping dealers better understand their valueadded functions and Web-enabling this process. For example, Ford or GM might gain dealer cooperation by jointly developing (with their dealers) a site where car owners might be able to view maintenance information and recall notices, obtain insurance and warranties, arrange credit and financing, and custom order. This effort would create mutual benefits for both the automakers and their dealers.

\section{Cell 3: Relational $\times$ Increased Reach}

The Web offers the possibility of reaching new customers more cheaply and efficiently than in the past. This potential can be more easily exploited in a relational rather than in a transactional context. In a relational context, the firm is concerned about mutual outcomes-it is critical that both it and the distributor or supplier gain some outcome from every new opportunity that is jointly pursued. By framing the use of the Internet as an opportunity that helps both the firm and its partner, the partner is less likely to view the use of the Internet to expand the reach of the firm as a threat to its well being.

One approach that has been used successfully is to demonstrate a continual reliance on the partner by taking the order from the customer, but then passing it along to the channel member for fulfillment, and compensating the channel member for the order. ${ }^{11}$ This is the approach of Hewlett-Packard, which takes customer orders on its Web site and funnels them to their intranet, which is tightly integrated with their reseller's home pages. The reseller completes the order, ships the product, and gets the commission. Although HP paid for the technology investment, it still provides its business partner with an $8 \%$ margin solely for fulfillment. In this manner, HP manages to separate the function of demand creation from fulfillment; HP understands that distribution partners, rather than merely moving boxes, provide a valued service that is worth compensating. The strategy of crediting commissions, regardless of where the sale originates, is based on the idea that various sales channels work together with an emphasis on relationships. Companies with such an emphasis realize that integrating their Web infrastructure across the supply chain ultimately benefits the end-customer, which works to the advantage of all players. 
Similarly, Estée Lauder was one of the first cosmetics companies to use an on-line channel to sell to consumers. It believes that collaborating with business partners is the best way to take advantage of the Web. For example, its Bobbi Brown cosmetics line is available at only 125 places across the United States. Allowing women at other locations to order the products is a sure way to increase reach and find new customers. However, when a woman orders products from the bobbibrowncosmetics.com Web site, she won't be buying directly from Bobbi Brown. Orders from the Web site are transferred to retailer Neiman Marcus, who then makes the sale to the customer. Estée Lauder follows a similar strategy with its Clinique products. It never duplicates the promotions that are run to drive traffic into retail stores, and it actively tries to drive such traffic to its retailers' own Web sites. Estée Lauder's vice president of special markets and new media recognizes that effective use of the Web is based on relationships, and not just technology.

In both of these examples, the manufacturer recognizes that the channel partner plays a vital role. By creating a win-win situation, the manufacturer is able to improve customer service, improve the quality of the relationship and level of cooperation, and is met with less channel resistance.

Another approach that works well in a relational context is to proactively communicate with the channel member about how the change will affect it. Recall the example about Herman Miller, who reached out to their distributors to assure them that their viability would not be threatened. Other firms manage the channel relationship by rewarding the partner's receptiveness and support of the Internet. DaimlerChrysler's new dealer-rating systems reward dealers who become more Net-friendly. Their Five Star dealership program funnels sales leads from the company's Web site only to the dealers who have met the automaker's new standards for service, facilities, and Internet savvy. GM sends leads from its BuyPower Web site to only $75 \%$ of its dealers, including those that respond to customer requests received through the Internet within 24 hours.

\section{Cell 4: Transactional XIncreased Reach}

When the firm has developed transactional exchanges with its suppliers or distributors, it tends to be concerned solely about its own welfare. As a result, using the Internet as a means to expand its reach can be viewed as a threat by the current distributors or suppliers. This is because a transaction-oriented philosophy does not guarantee that the benefits arising from increased reach would extend to existing exchange partners; in fact, increased reach could diminish their share of the pie. The use of electronic marketplaces to identify new suppliers could mean that their business would move to new suppliers or that existing distribution channel members would be bypassed. This could result in considerable backlash from suppliers or distributors.

Nowhere has this been more starkly demonstrated than in the automotive industry. Relationships between dealers and manufacturers have been contentious for decades. On the one hand, manufacturers would like to expand 
their activities from merely building cars to offering a range of automotive services that are currently supplied by dealers. On the other hand, dealers control access to the $\$ 350$ billion new-vehicle business. In the late nineties, car manufacturers courted the possibility of selling directly to consumers, and bypassing the dealers. The dealers fought back, setting up Web sites, buying online services and posting invoice prices over the Net. In essence, they created their own online retailing world in which they play a major role. They also pushed legislation prohibiting carmakers from using the Web or any other means to sell directly to customers. In September 1999, 32 states had such laws in place; 12 more states were added over the next 6 months. The rise of the Internet and the manufacturers' moves to increase reach through the Web have resulted in dealers nationally coordinating themselves, consolidating their clout, and making significant, credible threats.

This scenario has played out in other industries ranging from liquor to consumer packaged goods to PCs. In the liquor industry, wine distributors have pushed for the outlaw of alcohol sales over the Internet. At least 20 states now prohibit such sales; three of these states have made it a felony to ship alcohol directly to consumers. Many retailers have used such strong-arm tactics to pressure their suppliers into avoiding an on-line, direct-to-consumer sales channel. Manufacturers, fearful of retailers' wrath, have succumbed to such adversarial tactics.

Rubbermaid's site displays all of its various products, but doesn't allow a consumer to place an order. Maytag dealers were outraged when Maytag unveiled its plans for on-line e-commerce; Maytag hastily pulled the plug on its strategy. Home Depot was more proactive in stating its position with its 5,000 suppliers: It sent a letter to them affirming the suppliers' rights to sell through on-line channels, and ended with a threat: "if a supplier chooses to become a retailer, they will become a competitor....we would be hesitant to do business with competitors." ${ }^{12}$ The earlier scenario of Compaq Computer and its dealers is also relevant here. These dealers viewed the Internet channel as a threat to their existing business. Since their relations with Compaq had been strained, they did not believe Compaq's claim that the new channel would target different customers. Hence, their relationship soured as dealers refused to cooperate. Customer service suffered, and channel resistance to the initiative increased. The transactional context that was in place between Compaq and its dealers played a large role in preventing Compaq from quickly recovering from their mistakes and avoiding the conflict that it experienced.

The coercive use of power exercised by retailers is one indicator of the transaction-oriented nature of these relationships. When these manufacturers attempted to sell their products online in order to reach more customers, dealers retaliated with credible threats to stop carrying their products, and thus, persuaded them to retreat from any efforts to sell through the Web. 


\section{Cell 5: Relational $\times$ Dynamic Pricing}

The recent popularity of online auctions for both sales and procurement activities demonstrates the Web's potential to enable dynamic pricing strategies in B2B e-commerce. However, the emerging picture on the use of online auctions is mixed, particularly in sourcing activities. Specifically, in a long-term, relational exchange context, these auctions may seem counter to successful continuity of these relationships. Consider the following statements by suppliers:

"I am the general manager of a small manufacturing company and I appreciate the opportunity to express my views concerning e-auctions. We are a supplier and very recently had this experience with our major customer. To sit for five hours and watch business that you have developed, maintained, and serviced for forty years being carved up and slowly disintegrate is a very traumatic experience. Are we seeing the demise of a purchasing staff and sales force, as we know it today?" -Jack Bailey, Purchasing, June 15, 2000

"[The buyer] talks about the relationship being a partnership and this [the auction] really takes that away. There is not a partnership there at all. What they do is take your existing business that you have worked very hard to achieve and maintain. You work with them to give them cost reductions over the years and they send it out across the board for a competitive bid. I just do not think that is fair."-[anonymous supplier]

Many suppliers now rue the day that reverse auctions entered the B2B marketplace. Our own research in this area indicates that they often believe that buyers use reverse auctions as an opportunistic means by which to wrestle further price concessions and view market pricing. ${ }^{13}$

We have also witnessed a significant disconnect between supplier perceptions of the auction experience and the reality of the event. Specifically, we found that suppliers believe that buyers use online reverse auctions as a means to survey the market pricing without any intention of awarding the business. They also believe that the buyer creates false competition by including nonviable bidders who don't have the capabilities to take the business. In some cases, they believe that buyers "shill" their bids. Shilling is an unethical practice in which the buyer acts as a competitive supplier and places bids against suppliers as an attempt to artificially push the price down farther.

The irony here is that none of the supplier perceptions match reality. As independent observers at a number of events, we knew that buyers had every intention of selecting a winner and had invited only viable suppliers to bid in the business. None of the buyers bid in their auction events against their suppliers. In fact, the buyer and auctioneer went to great pains to insure to avoid such perceptions. They clearly told suppliers that a winner would be selected; all participating suppliers were prequalified, viable alternatives to the buyer; and the buyer was not allowed to bid against them. Despite these textbook efforts, suppliers refuse to believe that these conditions were true. Thus, there is a significant gap between supplier perceptions of the event and reality, and this gap should be cause for concern. 
Another key frustration for many suppliers is that many auction formats allow only price differences to be expressed. Other key factors that are important in direct sourcing activities-such as quality, value-added services, and reliability-are not expressed. In relational exchanges, both parties receive many non-economic benefits, such as improved communication and coordination, responsiveness, and other aspects beyond the terms of the contract. Auctions seem to undermine and threaten the existence and value of these benefits. As such, when firms in relational contexts decide to incorporate Web-enabled dynamic pricing, they may discover that it has a damaging effect on their ability to serve customers, hinder the relationship quality and cooperation with the other firm, and increase partners' resistance to the use of the Internet in their relationship. This was the experience of the Grant J. Hunt Company, a business that specializes in buying produce from farmers and reselling it to grocers. Hunt opted to forgo participating in on-line exchanges such as BuyProduce.com, stating that "none of the exchanges could duplicate the personal attention" to his customers and convey the finer points of the quality of the produce to his buyers. His business success is based on the trust that he has built up in his industry over a period of generations, which cannot be duplicated on the Web. ${ }^{14}$

In general, auctions can have a harmful effect on relational exchanges. This is consistent with the comments of Roger A. Whittier, director of corporate purchasing for Intel Corporation:

“Intel has run several successful auctions to move surplus equipment and material. [However,] we haven't had that much interest out of buyers. Frankly, when you go to buyers and say we want to start reverse auctions, they feel very threatened by it. They feel they add value as negotiations and through sourcing and so forth. In any kind of business where you actually make a difference by negotiating, picking specifications and having some kind of relationship, then reverse auctions don't make a lot of sense. ${ }^{15}$

However, this does not mean that firms should never use reverse auctions. There can be a silver lining to the occasional use of such events. We have found that they also increase the incumbent supplier's willingness to make dedicated investments toward the buyer. ${ }^{16}$ This stems from the supplier's desire to avoid a continuous cycle of auctions and signal a determination to remain in the buyer's supply base in the long run. Hence, one approach that considers these aspects, while still capitalizing on the short-term financial gains that auctions offer, is to use a reverse auction as a pre-cursor to a longer-term, strategic sourcing agreement. In this manner, a buyer can not only quickly sort various supply candidates on the basis of price, but also mitigate the long-term development of opportunism suspicion and capitalize on the supplier's willingness to create extra value for the buyer. The John Deere Company has tried to bring the conflicting notions of reverse auctions and deep supplier relationships together. Although its e-sourcing work has shrunk the number of MRO suppliers from 1,975 to just 20 , it works very hard to maintain close ties with the suppliers that it retains. As David Nelson, VP of worldwide supply management at John Deere, says: 
because "suppliers' quality, delivery, and costs are [John Deere's] quality, delivery, and costs," such relationships are a matter of survival. ${ }^{17}$ Another solution to this problem is to use reverse auctions only for indirect purchases of commoditized products or in transactional exchange contexts.

\section{Cell 6: Transactional $\times$ Dynamic Pricing}

When the firm has transactional exchanges in place with its distributors or suppliers, then dynamic pricing can have a very positive effect on the firms' productivity and the transactional efficiency between them. When firms use open-bid, price-competition mechanisms-where each bidder can view the bid price of other bidders-the firm can gain significantly more revenues or savings than when a sealed (private) bid pricing mechanism is used.$^{18}$ In fact, the online reverse auctions used in sourcing activities has been shown to achieve gross savings from $5-40 \%$ (with an average of $15-20 \%$ being more typical). In industries where growth rates are low or firms are not able to raise competitive pricing, cost reduction is an extremely attractive alternative. For a business earning a $20 \%$ gross margin, a $\$ 1$ decrease in costs is equivalent to a revenue increase of $\$ 5$. Our own survey of auction users indicates that prior to the auction, they expected to save on average $11 \%$ over historical costs. In reality, they saved $18 \% .{ }^{19}$ This has been a major impetus to the continued and growing use of auctions in sourcing activities, and it has led a number of organizations to conclude:

"Reverse auctioning and strategic sourcing provide the quickest paybacks among most (if not all) IT implementations."-David Scott Lewis, META group, September 2001

Some B2B e-marketplaces facilitate the purchase and sale of surplus equipment or materials (such as FreeMarkets.com and MetalSite.com). Other sites (such as Askad.com) auction surplus advertising inventory, allowing firms to capture a portion of advertising revenue that otherwise might have been lost and enabling advertisers to gain additional impressions at a significant discount. In transactional exchange contexts, the relationship beyond the exchange has little value and is not put at risk. Firms in these exchanges may already have a -strong price-focus. Taking this approach on-line simplifies and supports this ongoing process.

In the supply chain, this would mean that using Web-enabled dynamic pricing models for indirect or commoditized purchases could make a lot of sense. This may explain why we have seen reverse auctions increasingly adopted by a number of industries and trade sectors over recent years. ${ }^{20}$ They first became popular in low-growth industries such as manufacturing, with companies such as Boeing, SPX/Eaton, United Technologies, and the United States military branch making significant purchase volumes through such auctions. Over time, consumer product companies such as Quaker, Nestlé, and Emerson Electronics have also adopted reverse auctions. Furthermore, in the wake of the dot-com bust, a number of high-tech firms such as Dell, Hewlett-Packard, Intel, and Sun 
Microsystems have introduced dynamic pricing through electronic reverse auctions in their sourcing activities.

Currently, approximately $\$ 40$ billion in throughput is placed in these auctions, however the global 500 have an addressable spend of $\$ 6.3$ trillion. This indicates that there is still a significant volume of transactions that can benefit from online, reverse auctions. When online reverse auctions are done correctly in transactional contexts, buyers can achieve cost savings, access new sources of supply, gain market pricing, and improve transactional efficiencies that decrease the ultimate cost of goods sold and have an impact on the bottom line.

\section{Conclusions}

The B2B context and emerging Internet technologies can be combined to improve customer service, relationship quality and cooperation, and decrease channel resistance. The Relationship $\times$ Technology matrix helps us understand why firms who attempt to use the Internet in a similar manner can experience very different outcomes. The interplay between the capabilities of emerging technologies and the relationship contexts in which these technologies are being placed highlights the need to systematically understand their interdependence. By doing so, firms have a better chance of improving the productivity created by technology investments.

In particular, when firms want to use the Internet to improve information sharing and customer reach, these goals are best accomplished in a relational context. If the firm doesn't have relational exchanges in place, its options are either to develop relational exchanges or to consider alternative ways to use the Internet. Of course, developing more collaborative relationships with partners along the supply chain cannot be accomplished overnight-particularly if there is a long history of a more transaction-oriented approach. Working to establish more collaborative communication would be a start in changing relationship dynamics. ${ }^{21}$ If the goal of the firm is to incorporate more dynamic pricing into its exchanges, it should do so in those exchanges that are transactional in nature and it should avoid using such approaches in relational exchanges, particularly . without appropriate precautions. In a similar manner, the firm can consider the types of relationships that already exist in its distribution or supply chain. Productivity can be improved in relational exchanges by using the Internet as a means by which to share information more completely and to reach out to new customers. Transactional relationships will benefit from the use of dynamic pricing structures that are Web-enabled.

If firms consider the $\mathrm{B} 2 \mathrm{~B}$ relationship more systematically in their Internet strategies, the payoffs from doing so can be enormous. By properly matching the B2B context with Internet technologies, corporations can free up scarce human resources to do more value-added activities. Cisco has found that by automating the routine marketing and selling activities of their sales force, salespeople were able to focus on more complex activities, including customization of 
products, market analysis, and proactive marketing to high-potential customers. At Carlson Wagonlit Travel, shifting sales of routine products such as short-haul shuttle flights to the Web has freed up their travel agents to do more marketing to high-potential customers. Financial services companies with thousands of institutional investors can improve their servicing, retention, and penetration of these investors via electronic sales interfaces that can help prospect and identify top customers to their sales force.

When the B2B relationship context is properly matched with Web strategies, the firm can experience a direct impact to its bottom line via improved satisfaction and loyalty. The value of a good matching is increasingly evident. Many Web customers tend to consolidate their purchases with a primary supplier over time, ${ }^{21}$ further raising the stakes in getting the B2B relationship/technology interface right. WW Grainger had reached a point where purchase volumes through its branches had stabilized. However, after offering a Web channel, sales to these same customers increased at triple the rate of the customers who used only the physical outlets. Getting the Relationship $\times$ Technology interface right should be a top priority in any e-commerce strategy.

Once this is done at a basic level, the same logic can be extended to a multichannel strategy. Consider Dell's corporate customers, all of whom have relational exchanges in place with Dell. Since the introduction of their Premier Pages nearly a decade ago, Dell's customers now work with Dell through a variety of channels - the sales force, the Internet, mail, and other Dell outlets such as DellAuction.com and DellNet. Similarly, Grainger has seamlessly integrated their Web channel with their commissioned sales force. Although $25 \%$ of Grainger's Web orders occur when the branches are closed, sales reps are still paid commissions, regardless of which channel customers use. In this way, the sales reps always have customer interests and convenience in mind. Grainger's goal is to earn higher shares of the customer's business, not bypass its sales force to reduce costs. As a result, their customers' Web purchases are more than double the rate of the overall industry. Home Depot has also integrated their bricks and clicks. They have developed Web sites that serve a profitable segment: small contractors. These sites provide value to the contractors, enabling them to monitor orders and learn more information about Home Depot.

Too often, we observe firms who throw technology at their distribution channel or supply chain, only to be disappointed with the returns from these investments. Although leveraging technology in B2B relationships is a complex task that needs to be thoughtfully planned and carefully executed, clearly the payoffs in $\mathrm{B} 2 \mathrm{~B}$ e-commerce are there and yet to be realized. Considering the match between the $\mathrm{B} 2 \mathrm{~B}$ relationship context and emerging technologies brings us one step closer to the prize. 


\section{Notes}

1. Michael Pastore, "\$6 Trillion in B2B Trade by 2005," CyberAtlas (June 2000), $<$ http://cyberatlas.internet.com/markets/b2b/article/0,,10091_402421,00.html>.

2. "B2B E-Commerce Will Survive Growing Pains," CyberAtlas (November 2001), <http://cyberatlas.internet.com/markets/b2b/article/0,,10091_930251,00.html>.

3. Ibid.

4. David Wessel, "The Magic Elixir of Productivity," Wall Street Journal, February 15, 2001.

5. Ibid.

6. Rochelle Garner, "Mad as Hell," Sales and Marketing Management, June 9, 1999, pp. 54-61.

7. Fortune, September 6, 1999.

8. Sandy D. Jap, “'Pie-Expansion' Efforts: Collaboration Processes in Buyer-Supplier Relationships," Journal of Marketing Research, 36/4 (1999): 461-475.

9. David Welch, "Fear and Loathing in the Showroom," Business Week, February 28, 2000.

10. Robert L. Simison, “GM Retools to Sell Custom Cars Online," Wall Street Journal, February 22, 2000, p. B23.

11. Jakki Mohr, Marketing of High-Technology Products and Innovations (Upper Saddle River, NH: Prentice-Hall Business Publishing, 2001), Chapter 8.

12. Neil Weinberg, "Not.coms," Forbes, April 7, 2000.

13. Sandy D. Jap, "The Impact of Online, Reverse Auctions on Buyer-Supplier Relationships," working paper, MIT Sloan School of Management, 2001.

14. Lee Gomes, "How Lower-Tech Gear Beat Web 'Exchanges' at Their Own Game," Wall Street Journal, March 16, 2001, pp. A1, A6.

15. Purchasing, June 21, 2001, p. S2.

16. Jap (2001), op. cit.

17. Jim Ericson, "Reverse Auctions: Bad Idea?" Line 56.com Magazine, September 20 , 2001.).

18. Paul R. Milgrom and Robert J. Weber, "A Theory of Auctions and Competitive Bidding," Econometrica, 50 (1982): 1089-1122.

19. Sandy D. Jap, "Online, Reverse Auction: Issues, Themes, and Prospects for the Future," Journal of the Academy of Marketing Science-Marketing Science Institute, Special Issue on Marketing to and Serving Customers Through the Internet: Conceptual Frameworks, Practical Insights and Research Directions, (forthcoming, 2002).

20. Nathan Smith, "Dynamic Pricing Effects on Strategic Sourcing and Supplier Relations," Leaders for Manufacturing Thesis, Massachusetts Institute of Technology, 2002.

21. Jakki Mohr, Robert Fisher, and John Nevin, "Integration and Control in Interfirm Relationships: The Moderating Role of Collaborative Communication," Journal of Marketing, 60 (July 1996): 103-115.

22. Frederick Reichheld and Phil Schefter, "E-Loyalty: Your Secret Weapon on the Web," Harvard Business Review, $78 / 4$ (July/August 2000): 105-113. 